\title{
KOLEKTIVNI UGOVORI KAO IZVOR PRAVA ZA REGULIRANJE RADNOG STATUSA POMORACA U REPUBLICI HRVATSKOJ
}

Prof. dr. sc. Ivo Rozic**

Tony Vuković, mag. iur.**

Dr. sc. Nenad Božiković***
UDK 331.106.24: 347.793

349.2

https://doi.org/10.30925/zpfsr.42.3.6

Ur.: 24. svibnja 2021.

Pr.: 28. rujna 2021.

Prethodno priopćenje

\section{Sažetak}

Radni status pomoraca jedan je od najspecifičnijih radnih statusa. Pomorci su posebna kategorija radnika, jer im je mjesto rada ujedno i mjesto življenja, te im se uvjeti života i rada u mnogočemu razlikuju od uvjeta rada $i$ života radnika u drugim gospodarskim djelatnostima koje se obavljaju na kopnu. Stoga je posebno važno pravno reguliranje radnog statusa pomoraca. Najveći uspjeh po pitanju radnopravnih odnosa pomoraca učinjen je usvajanjem Konvencije o radu pomoraca iz 2006. (MLC), koju je Republika Hrvatska ratificirala u veljači 2010. U Republici Hrvatskoj ne postoji cjelovit pravni akt kojim bi se uredili radni, socijalni i životni uvjeti pomoraca, već takve odredbe obuhvaćaju više propisa. Posebno važan izvor prava su kolektivni ugovori. U Republici Hrvatskoj na snazi su dva takva kolektivna ugovora - Nacionalni kolektivni ugovor za hrvatske pomorce na putničkim brodovima i trajektima sklopljen 1998. i Nacionalni kolektivni ugovor za hrvatske pomorce na brodovima u međunarodnoj plovidbi (2021.-2022.) koji je u primjeni od 2021. U radu autori daju osvrt na Konvenciju o radu pomoraca, značajke pojma i procesa kolektivnoga pregovaranja, a posebno analiziraju važeće kolektivne ugovore s fokusom na Nacionalni kolektivni ugovor za hrvatske pomorce na brodovima u međunarodnoj plovidbi (2021.-2022.).

Ključne riječi: radnopravni status pomoraca; Konvencija o radu pomoraca (MLC); kolektivno pregovaranje; Nacionalni kolektivni ugovor za hrvatske pomorce na putničkim brodovima i trajektima; Nacionalni kolektivni ugovor za hrvatske pomorce na brodovima u međunarodnoj plovidbi.

* Dr. sc. Ivo Rozić, redoviti profesor, Sveučilište u Mostaru, Pravni fakultet; ivo.rozic@pf.sum. ba. ORCID: https://orcid.org/0000-0003-0074-1450.

** Tony Vuković, mag. iur., doktorand Sveučilište u Mostaru, Pravni fakultet; tonyvukovich@, pfst.hr. ORCID: https://orcid.org/0000-0003-3370-1324.

*** Dr. sc. Nenad Božiković, vanjski suradnik visoke škole Banja Luka College; jbozikovina@, gmail.com. ORCID: https://orcid.org/0000-0001-6140-0639. 


\section{UVOD}

Pomorci su jedna od najlošije tretiranih skupina radnika. Zbog toga su društveni odnosi povezani s plovidbom i morem predmet zakonskoga normiranja još od davnina. ${ }^{1}$ Radni uvjeti i radnopravna zaštita daleko su ispod razine radnih uvjeta $\mathrm{i}$ radnopravne zaštite drugih skupina radnika zbog činjenice da se sustav pomorskog prava još uvijek uvelike oslanja na zastarjelim načelima jurisdikcije i zbog izvora međunarodnoga radnog prava kojima nedostaje jasnoća i univerzalna primjenjivost koja bi utjecala na razvoj radnih odnosa u pomorskoj industriji. ${ }^{2}$

U suvremenom odvijanju pomorskog prometa, veći broj brodova koji viju zastave pogodnosti, razvoj globalnoga tržišta rada, rapidni tehnološki razvoj zbog kojeg brodovi sve kraći borave u luci, kao i brža cirkulacija roba i usluga, pridonijeli su povećanju međunarodne kompetitivnosti u pomorskoj djelatnosti i povećanom pritisku za smanjenje troškova. Smanjenje troškova ponajprije se postiže snižavanjem standarda u području rada i sigurnosti na radu na način da se izbjegavaju regulatorni režimi u području rada i radnih odnosa i nacionalnih i međunarodnih, ali i smanjenjem plaća, pogoršanjem uvjeta života i rada pomoraca na brodu, kao i angažiranjem relativno jeftine i neiskusne radne snage različite nacionalnosti. ${ }^{3}$

Zaštita je pomoraca ključna, ne samo radi osiguranja sigurnosti plovidbe, a time i zaštite morskog okoliša, već i radi zaštite sigurnosti i zdravlja pomoraca, a osobito u kontekstu zaštite njihovih temeljnih ljudskih prava. U svjetlu navedenoga, Međunarodna organizacija rada (engl. International Labour Organization - ILO, dalje: MOR) prepoznala je potrebu izrade dokumenta koji će pravno osnažiti radne standarde u području pomorstva, stoga je 2006. donijela Konvenciju o radu pomoraca (engl. Maritime Labour Convention, dalje: MLC) koja je najvažniji dokument vezan za uređenje radnopravnog statusa pomoraca. ${ }^{4}$

U Republici Hrvatskoj (dalje: RH) društveni odnosi koji se tiču mora i plovidbe počeli su se regulirati pojavom statuta u 14. stoljeću. Statuti na istočnoj obali Jadranskog mora podijeljeni su u dva dijela, sjeverne koji su pod utjecajem Venecijanskih Statuta navium ili Capitulare natuticum od 1255. (npr. Zadarski i Splitski statut) i južne koji su pod utjecajem Dubrovačkog statuta iz 1272. (npr. Hvarski i Kotorski statut). ${ }^{5}$ Danas u RH ne postoji cjelovit pravni akt koji bi uredio radne,

1 Željko Bartulović i Maja Aflić, „Sailor’s Service from Medieval Times to Modern Maritime Labour Conventions“, Zbornik Pravnog fakulteta Sveučilišta u Rijeci 55, br. 1 (2018): 167.

2 John Issac Blanck, ,Reflections on the Negotiation of the Maritime Labour Convention 2006 at the International Labour Organisation“, Tulane Maritime Law Journal 31, br. 35 (2006-2007): 36.

3 Andrijana Bilić i Vanja Smokvina, „Problems and Perspectives of Seafarers' labour contracts in the light of Maritime Labour Convention with special refrence to Croatian legislation“" u: Zbornik radova - 3. Međunarodna znanstvena konferencija pomorskog prava Suvremeni izazovi pomorske plovidbe, ur. Petra Amižić et. al. (Split: Sveučilište u Splitu, Pravni fakultet, 2021.), 12.

4 Bilić, Smokvina, Problems and Perspectives of Seafarers' labour contracts in the light of Maritime Labour Convention with special refrence to Croatian legislation, 13.

5 Bartulović, Aflić, Sailor's Service from Medieval Times to Modern Maritime Labour Conventions, 168. 
životne i socijalne uvjete hrvatskih pomoraca, već su te odredbe obuhvaćene u više propisa od kojih su najvažniji Pomorski zakonik ${ }^{6}$ (dalje: PZ), Nacionalni kolektivni ugovor za hrvatske pomorce u međunarodnoj plovidbi, ${ }^{7}$ Nacionalni kolektivni ugovor za hrvatske pomorce na putničkim brodovima i trajektima, ${ }^{8}$ međunarodni ugovori koji su sklopljeni i potvrđeni u skladu s Ustavom RH i objavljeni te Zakona o radu ${ }^{9}$ (dalje: ZOR). Odredbe PZ-a, međunarodnih ugovora koji obvezuju RH te kolektivnih ugovora koji uređuju radnopravne odnose za pomorce u međunarodnoj plovidbi, imaju prednost pred odredbama ZOR-a. ${ }^{10} \mathrm{RH}$ je od 2018. do 2020. imala oko 15.300 pomoraca u međunarodnoj plovidbi i oko 7.000 pomoraca u nacionalnoj plovidbi. ${ }^{11}$

U prvom dijelu rada autori se osvrću na MLC te njenu važnost za radnopravni status pomoraca. U drugom dijelu autori obrađuju pojam kolektivnih ugovora općenito, kao i kolektivnog pregovaranja koje prethodi sklapanju kolektivnih ugovora. U trećem dijelu autori analiziraju dva nacionalna kolektivna ugovora koja su na snazi - Nacionalni kolektivni ugovor za hrvatske pomorce na putničkim brodovima i trajektima i Nacionalni kolektivni ugovor za hrvatske pomorce u međunarodnoj plovidbi. Poseban se naglasak stavlja na analizu Nacionalnog kolektivnog ugovora za hrvatske pomorce u međunarodnoj plovidbi (2021.-2022.) te njegov utjecaj na poboljšanje radnih, socijalnih i životnih uvjeta pomoraca u međunarodnoj plovidbi.

\section{KONVENCIJA O RADU POMORACA}

MOR je utemeljena nakon Prvoga svjetskog rata na Mirovnoj konferenciji u Parizu 1919., sa zadaćom podupiranja država u kreiranju radnopravnoga zakonodavstva i drugih propisa kojima bi se osigurali humani uvjeti života i rada radnika, kao i ograničenje moći poslodavaca u smislu sprječavanja njihove eksploatacije. MOR trenutačno ima 187 država članica, ${ }^{12}$ a jedinstvena je po svojoj tripartitnoj strukturi u kojoj radnici i poslodavci sudjeluju u radu upravnih tijela organizacije kao ravnopravni partneri vladama.

MOR je u sklopu svoje normativne djelatnosti donijela ukupno 190 konvencija, 206 preporuka te 6 protokola. ${ }^{13}$ Temeljna razlika između konvencija i preporuka MOR-a je da su konvencije pravno-obvezujući normativni instrumenti za države članice koje su ih ratificirale (dobivaju snagu zakona), dok su preporuke savjetodavnoga

6 Pomorski zakonik, Narodne novine, br. 181/04., 76/07., 146/08., 61/11., 56/13., 26/15. i 17/19.

7 Nacionalni kolektivni ugovor za hrvatske pomorce u međunarodnoj plovidbi, Narodne novine, br. $6 / 21$.

8 Nacionalni kolektivni ugovor za hrvatske pomorce na putničkim brodovima i trajektima, pristup 16. ožujka 2021., http://www.nsppbh.hr/cms.

9 Zakon o radu, Narodne novine, br. 93/14., 127/17. i 98/19.

10 Čl. 125., st. 5. i 7. Pomorskog zakonika.

11 Sindikat pomoraca Hrvatske, pristup 18. prosinca 2020., www.sph.hr.

12 Međunarodna organizacija rada, pristup 13. veljače 2021., www.ilo.org/global/about-the-ilo.

13 Daniel Maul, The International Labour Organization, 100 years of global social policy (Berlin: De Gruyter Oldenbour, 2019.), 8. 
karaktera. ${ }^{14}$ MOR ne može primorati države članice na ratifikaciju konvencija. ${ }^{15}$

Zbog činjenice da su pomorci posebna kategorija radnika, najveći broj konvencija i preporuka MOR-a donesen je upravo u svezi s radom pomoraca. Međutim, analizirajući 122 države, koje su ratificirale barem jednu konvenciju koja se odnosi na pomorce, dolazi se do podataka da je samo 10 država ratificiralo dvadeset ili više konvencija koje se odnose na pomorce. ${ }^{16}$

Najveći uspjeh po pitanju radnopravnih odnosa pomoraca učinjen je usvajanjem MLC-a. Usvojen je nakon pet godina pregovaranja na 94. sjednici MOR-a održanoj 7.-23. veljače 2006. u Ženevi, kao rezultat tripartitnoga sporazuma vlada, sindikata pomoraca i predstavnika brodovlasnika. RH je ratificirala MLC u veljači 2010. te je svoje nacionalno zakonodavstvo uskladila s njenim odredbama.

U MLC-u je propisano da će stupiti na snagu dvanaest mjeseci nakon što je ratificira 30 država, ali uz uvjet da te države čine najmanje $33 \%$ svjetske bruto tonaže. ${ }^{17}$ Zbog činjenice da je Europska unija donijela preporuku ${ }^{18}$ svojim državama članicama da do kraja 2010. ratificiraju MLC, taj se uvjet ispunio relativno brzo i to 2012. MLC je stoga stupio na snagu u kolovozu 2013., a do sada ga je ratificiralo 106 država, ${ }^{19}$ odnosno preko $91 \%$ ukupne svjetske bruto tonaže.

Osim MOR-a u izradi i usvajanju MLC-a aktivno se uključila i Međunarodna pomorska organizacija (engl. International Maritime Organization, dalje: IMO). Cilj je MLC-a namjera uspostaviti dostojan rad za pomorce i jednake uvjete za brodovlasnike. ${ }^{20}$ Riječ je o konsolidiranom tekstu gotovo svih do tada donesenih radnopravnih standarda za pomorce zajamčenih u konvencijama MOR-a, ${ }^{21}$ ali uzimaju se u obzir standardi koje je uspostavio IMO u svojim konvencijama vezano za sigurnost na moru (Međunarodnu konvencija o zaštiti ljudskih života na moru; engl. International Convention for the Safety of Life at Sea - SOLAS), zaštiti morskog okoliša (Međunarodna konvencija o sprječavanju onečišćenja mora s brodova; engl. International Convention for the Preventional of Pollution from Ships - MARPOL) te usavršavanja pomoraca (Međunarodna konvencija o standardima izobrazbe, izdavanju

14 Gorana Jelić Mrčelić, Nikola Mandić, Ranka Petrinović, „Environmental Impact of Ships “, u: International Legislative Framework, ur. Stephen de Mora, Timothy Fileman, Thomas Vance (Cambridge: Cambridge University Press, 2020.), 334.

15 Boris Buklijaš, Andrijana Bilić, Međunarodno radno pravo (Split: Sveučilište u Splitu, Pravni Fakultet, 2006.), 54.

16 Bilić, Smokvina, Problems and Perspectives of Seafarers' labour contracts in the light of Maritime Labour Convention with special refrence to Croatian legislation, 19.

17 Bruto tonaža definira se kao mjera cijele veličine broda, utvrđene u skladu s odredbama Konvencije o baždarenju brodova iz 1969. tj. bruto tonaža dobiva se množenjem zapremnine svih zatvorenih brodskih prostora $\mathrm{s}$ jednim promjenjivim faktorom koji je funkcija veličine spomenutih prostora. Vidi opširnije u Ivo Grabovac i Ranka Petrinović, Pomorsko pravo, pomorsko javno, upravno i radno pravo (Split: Sveučilište u Splitu, Pomorski faklutet, 2006.), 59.

18 Odluka Vijeća EU 2997/431/EC od 7. lipnja 2010.

19 Međunarodna organizacija rada, pristup 16. veljače 2021., www.ilo.org/global/about-the-ilo.

20 Moira L. McConnell, „The Maritime Labour Convention, 2006 - reflections on challenges for flag State implementation “, WMU Journal of Maritime Affairs 10, br. 127 (2011): 132.

21 Tekstom MLC-a nisu obuhvaćene Konvencija br. 71 o mirovinama pomoraca iz 1946. te Konvencija br. 108 o nacionalnim ispravama pomoraca iz 1958. 
svjedodžbi i držanju straže pomoraca; engl. International Convenation on Standards of Training, Certification and Watchkeeping - STCW). ${ }^{22}$

MLC čine, uz preambulu, članci, pravila i kodeksi. Članci i pravila obuhvaćaju temeljna prava i načela kao i temeljne obveze članica MLC-a. Kodeks obuhvaća pojedinosti u vezi s primjenom pravila. Dio A Kodeksa (Standardi) je obvezujući, a dio B (Smjernice) obuhvaća preporuke koje bi države članice trebale uzeti u obzir kod donošenja nacionalnih propisa kojima se primjenjuje MLC. Pravila i kodeksi podijeljeni su u pet poglavlja.

Prvo poglavlje pod nazivom Najmanji zahtjev za rad pomoraca na brodu $u^{23}$ propisuje najnižu starosnu dob od 16 godina za prijam za rad na pomorskim poslovima. Uz to, svaki pomorac prije zapošljavanja na brodu mora imati zdravstvenu svjedodžbu koja je dokaz njegova psihofizičkoga zdravlja.

Drugi dio Uvjeti zaposlenja ${ }^{24}$ nameće obvezu ugovora o radu pomorca koji će obuhvatiti obvezne klauzule vezane za uvjete njegovog zapošljavanja. Zapošljavanje je jedno od važnijih pitanja za svaku zajednicu i pojedinca te obuhvaća materijalne i nematerijalne aspekte. ${ }^{25} \mathrm{U}$ ovom se poglavlju propisuje najduže razdoblje u kojem je poslodavac dužan isplatiti radniku plaću za obavljeni rad, kao i najdulje trajanje dnevnog i tjednoga radnog vremena, vrijeme odmora, pravo na repatrijaciju, korištenje godišnjeg odmora itd.

U trećem dijelu pod nazivom Prostorije za smještaj, prostorije za odmor, prehrana i posluživanje kave $^{26}$ osigurava se da pomorci imaju prikladne prostorije za smještaj i odmor, hranu i pitku vodu odgovarajuće kvalitete posluženu u primjerenim higijenskim uvjetima.

U četvrtom dijelu Zaštita zdravlja, zdravstvena skrb izaštita socijalne sigurnosti ${ }^{27}$ zahtijeva se odgovarajuća zdravstvena skrb na brodovima dostupna pomorcima koja se pruža na račun brodara, isplata plaće bolesnom ili povrijeđenom pomorcu koja se pruža na račun brodara, kao i isplata plaće bolesnom ili povrijeđenom pomorcu koji se nalazi na brodu te osiguranje pridržavanja standarda profesionalnoga zdravlja i sigurnosti.

Peti dio pod nazivom Usklađenost i provedba ${ }^{28}$ stvara obvezu svakoj državi članici da osigura da brodovi koji plove pod njezinom zastavom imaju Svjedodžbu o radu pomoraca (engl. Maritime Labor Certificate) i Deklaraciju o zadovoljavanju uvjeta rada pomoraca (engl. Declaration of Maritime Labor Compliance). Nadalje, posebno je važna obveza države zastave da obavlja nadzor nad brodovima svoje državne pripadnosti. Država luke ima pravo inspekcijskog nadzora na način da

22 Bilić, Smokvina, Problems and Perspectives of Seafarers' labour contracts in the light of Maritime Labour Convention with special refrence to Croatian legislation, 20-21.

23 „Konvencija o radu pomoraca“, Pomorski glasnik (Zagreb: Ministarstvo mora, turizma, prometa i razvitka, 2006.), 24-31.

24 Konvencija o radu pomoraca, 2006., 32-48.

25 Nenad Božiković, „Tržište rada u Europskoj uniji i Republici Hrvatskoj“, Zbornik Pravnog fakulteta Sveučlišta u Rijeci 42, br. 1. (2021): 103.

26 Konvencija o radu pomoraca, 2006., 49-62.

27 Konvencija o radu pomoraca, 2006., 63-82.

28 Konvencija o radu pomoraca, 2006., 83-100. 
provjerava ima li brod odgovarajuću svjedodžbu te jesu li uvjeti na brodu u skladu s odredbama MLC-a. Ako brod ne udovoljava spomenutim uvjetima, država luke ima pravo zaustaviti brod. Inspekcijski nadzor države luke odnosi se na sve brodove preko 500 bruto tona bez obzira na to je li njihova država ratificirala MLC.

Temeljne značajke MLC-a su:

- pružiti prikaz gotovo svih radnih i socijalnih prava pomoraca na jednom mjestu;

- predvidjeti stroga načela i prava za pomorce uz mogućnost fleksibilnog načina njene primjene u nacionalna zakonodavstva;

- osigurati jaki provedbeni režim kroz sustav certificiranja kao dokaz usklađenosti s MLC-om i njezinoga nadzora od strane kontrolnog sustava države luke;

- obuhvatiti klauzulu prema kojoj brod koji vije zastavu države koja nije ratificirala MLC neće biti stavljen u povoljniji položaj od onih koji viju zastavu države koja ju je ratificirala te

- pojednostavljuje postupak izmjena i dopuna. ${ }^{29}$

Člankom XIII. MLC-a propisano je osnivanje posebnoga tripartitnog odbora (engl. Special Tripartite Committee) koji će se baviti stalnim preispitivanjem odredbi MLC-a. Prema čl. 19. Ustava MOR-a (i čl. XIV. MLC-a), članci i pravila mogu se izmijeniti i dopuniti samo procedurom propisanom za usvajanje MLC-a. Međutim, kodeks se može izmijeniti pojednostavljenim postupkom utvrđenim u čl. XV. MLC-a. Budući da se Kodeks odnosi na detaljniju primjenu, njegove izmjene i dopune moraju ostati unutar općeg okvira članaka i pravila. ${ }^{30}$

Izmjene i dopune MLC-a do sada su usvojene tri puta i to 2014., 2016. i $2018 .{ }^{31}$ Zadnje izmjene i dopune koje su usvojene 27. travnja 2018., a stupile na snagu 26. prosinca 2020., odnose se na prava pomoraca u slučaju zatočeništva na brodu ili izvan njega koji su posljedica čina piratstva ili oružane pljačke brodova. Sve izmjene i dopune usmjerene su na proces poboljšanja životnih i radnih uvjeta.

\section{OPĆENITO O KOLEKTIVNIM UGOVORIMA I KOLEKTIVNOM PREGOVARANJU}

Današnje radno pravo u svijetu se ne može zamisliti bez kolektivnih ugovora koji imaju važnu gospodarsku, političku, socijalnu, humanitarnu i odgojnu funkciju. Kolektivni ugovor može se definirati kao pisani sporazum između sindikata i poslodavca koji obuhvaća odredbe o uvjetima zapošljavanja, načinima plaćanja, radnom vremenu

29 Bilić, Smokvina, Problems and Perspectives of Seafarers' labour contracts in the light of Maritime Labour Convention with special refrence to Croatian legislation, 38.

30 Ranka Petrinović, Trpimir Perkušić, Tony Vuković, „Inspection of Seafarers' working Conditions in Accordance with MLC 2006 in Ports of Paris MOU Signatories ", u: Zbornik radova - 3. Međunarodna znanstvena konferencija pomorskog prava Suvremeni izazovi pomorske plovidbe, ur. Petra Amižić et. al. (Split: Sveučilište u Splitu, Pravni fakultet, 2021.), 184.

31 Međunarodna organizacija rada, pristup 17. prosinca 2020., www.ilo.org/global/standards/ maritime-labour-convention/lang. 
i pravima ili obvezama ugovornih strana. ${ }^{32}$ Njime se stvara autonomno radno pravo, a naziva se socijalno zakonodavstvo.

Prema čl. 192. ZOR-a, kolektivnim se ugovorom uređuju prava i obveze stranaka koje su sklopile taj ugovor, a može obuhvaćati i pravna pravila kojima se uređuje sklapanje, sadržaj i prestanak radnih odnosa, pitanja socijalnog osiguranja te druga pitanja iz radnog odnosa ili u vezi s radnim odnosom.

ZOR-om je određeno da se kolektivni ugovori moraju sklapati u pisanom obliku kao i javno objaviti. ${ }^{33}$ Kolektivni ugovori mogu se sklapati na određeno ili neodređeno vrijeme. Pritom se kolektivni ugovor sklopljen na određeno vrijeme ne smije sklopiti za razdoblje duže od pet godina. Kolektivni ugovori mogu se sklapati i s otvorenim rokovima, kada ostaju na snazi sve dok bilo koja strana tog ugovora ne izrazi namjeru za revizijom, jer vrijedi sve dok ga priznaju obje strane.

Smisao je i cilj kolektivnog ugovora, s jedne strane ojačati pregovarački položaj zaposlenika, a s druge osigurati poslodavcu socijalni mir za ugovoreno vrijeme. ${ }^{34}$

Sklapanju kolektivnog ugovora prethodi postupak kolektivnog pregovaranja. Proces kolektivnog pregovaranja je dug i složen, međutim još je duži proces njegove primjene. $^{35}$

Kolektivno pregovaranje može se definirati kao metoda uređenja zarade, radnog vremena i ostalih uvjeta zapošljavanja kroz direktne pregovore između sindikata i poslodavca te je najčešći rezultat pregovaranja pismeni ugovor koji pokriva sve zaposlene u pregovaračkoj jedinici i članove sindikata i one koji to nisu. Stoga nije upitna primjena kolektivnog ugovora i na zaposlenike koji nisu članovi sindikata, dakle na sve radnike koji slijedom sklapanja ugovora uživaju sva prava, ali i obveze koje proizlaze iz sklopljenoga kolektivnog ugovora.

U postupku kolektivnog pregovaranja sudjeluju predstavnici koji s jedne strane zastupaju interese kapitala, a s druge interese rada. Osobe koje zastupaju stranke kolektivnog ugovora moraju imati pisanu punomoć za kolektivno pregovaranje i sklapanje kolektivnog ugovora. Ako je jedna od stranaka kolektivnog ugovora udruga poslodavaca ili udruga poslodavaca više razine, osobe koje zastupaju tu udrugu, uz pisanu punomoć, moraju drugoj strani dostaviti popis poslodavaca članova udruge $u$ čije ime pregovaraju, odnosno sklapaju kolektivni ugovor. ${ }^{36}$

Ako postoji javni interes, i ako su kolektivni ugovor sklopili sindikati s najvećim brojem članova i udruga poslodavaca koja ima najveći broj radnika, ministar nadležan za rad može na prijedlog svih stranaka kolektivnog ugovora proširiti primjenu

32 Ivo Rozić, Kolektivno radno pravo (Sarajevo: JP NIO Službeni list BIH, 2013.), 33-34.

33 Čl. 195. i čl. 202., st. 1. Zakona o radu.

34 Marina Šarac, Andrija Crnković, „Legal working status of crew members during the centuries - a comparative overview “ u: Zbornik radova - 3. Međunarodna znanstvena konferencija pomorskog prava Suvremeni izazovi pomorske plovidbe, ur. Petra Amižić et. al. (Split: Sveučilište u Splitu, Pravni fakultet, 2021.), 326.

35 Marinko Đ. Učur, Željko Bartulović, „Mornarska služba u srednjovjekovnim statutima i Nacionalni kolektivni ugovor za hrvatske pomorce na brodovima u međunarodnoj plovidbi “ $\mathrm{u}$ : Zbornik radova - Međunarodna znanstvena konferencija Uslužni poslovi, ur. Miodrag Mićović (Kragujevac: Pravni fakultet Kragujevac, 2013-2015.), 905. 
kolektivnog ugovora na poslodavca koji nije član udruge poslodavaca ili udruge poslodavaca više razine koja je potpisnica toga kolektivnog ugovora. ${ }^{37}$

Predmet stvarnoga pregovaranja dijelovi su kolektivnog ugovora o plaćama, naknadama, materijalnim i drugim pravima radnika i uvjetima rada. No, nisu manje bitni niti proceduralni elementi kolektivnog ugovora kao, npr. vrijeme sklapanja kolektivnog ugovora.

Cilj je kolektivnog pregovaranja postići kvalitetan dogovor, do kojeg se često dolazi kompromisom, popuštanjem stranaka u nekim od svojih prvobitnih zahtjeva te sklopiti kolektivni ugovor koji osigurava široku primjenu ugovorenog, rješavanje koristi subjekata, operativna i dugoročna rješenja i pouzdanost provedbe ugovorenoga. ${ }^{38}$

\section{NACIONALNI KOLEKTIVNI UGOVORI ZA POMORCE}

Kolektivni ugovori čine neposredni pravni temelj za ostvarivanje i zaštitu prava, obveza i odgovornosti pomoraca kod određenog brodara ${ }^{39}$ Kolektivni ugovor je sporazum kojeg pismeno sklapaju dvije legitimne strane kolektivnog pregovaranja - Sindikat pomoraca Hrvatske ${ }^{40}$ i predstavnici udruge brodara, na čijim su brodovima ukrcani pomorci.

Sindikat pomoraca Hrvatske član je Međunarodne federacije transportnih radnika (engl. International Transport Workers Federation, dalje: ITF). Sindikat pomoraca Hrvatske kao član ITF-a u svemu se drži minimalnih standarda utvrđenih u ITF-ovom osnovnom kolektivnom ugovoru.

Hrvatska udruga brodara Mare Nostrum utemeljena je 5. veljače 1991., na inicijativu 14 brodarskih društava pod nazivom Mare Nostrum - Hrvatsko pomorsko brodarsko društvo d.o.o. Zagreb. Trgovačko društvo preoblikovano je 2000. u udrugu te danas Mare Nostrum okuplja deset članica najvažnijih hrvatskih brodara ${ }^{41}$

Kolektivnim ugovorima za pomorce predviđen je minimum zajamčenih prava pomoraca. To znači da u pojedinačnom ugovoru o zaposlenju suugovaratelji mogu unijeti klauzule koje će još više ići u prilog zaposlenoga pomorca, dosljedno poštujući načelo in favorem laboratores. Time brodari svojim pravilnicima ne mogu umanjiti prava pomoraca predviđena kolektivnim ugovorom, koji, prema tome, ima

37 Čl. 203., st. 1. i 2. Zakona o radu.

38 Marinko Đ Učur, „Kolektivno pregovaranje i proširenje primjene kolektivnog ugovora“, Zbornik Pravnog fakulteta Sveučilišta u Rijeci 27, br.1 (2006): 550.

39 Marinko Đ Učur, „Nacionalni kolektivni ugovor za hrvatske pomorce na brodovima u međunarodnoj plovidbi (2013. - 2015.)“, Naše More 61, br. 5-6 (2014): 118.

40 Sindikat pomoraca Hrvatske ima sjedište u Rijeci, a glavni mu je zadatak unaprjeđenje i zaštita prava, interesa i društvenog položaja hrvatskih pomoraca i radnika čiji su poslovi povezani s pomorskom djelatnosti.

41 Članovi udruge su sljedeći brodari: Jadrolinija Rijeka; Jadranski pomorski servis d.d. Rijeka; Rapska plovidba d.d. Rab; Atlantska plovidba d.d. Dubrovnik; Tankerska plovidba d.d. Zadar; Jadroplov d.d. Split; Brodospas d.d. Split; Brodosplit-Plovidba d.o.o. Split; Alpha Adriatic d.d. Pula (bivši Uljanik Plovidba d.d. Pula) te Hrvatski registar brodova i Golar Viking Management d.o.o. Split kao pridruženi članovi. Navedeni brodari upravljaju sa 127 brodova. 
derogativan učinak prema općim aktima brodara. ${ }^{42}$

Kolektivni ugovori za pomorce razlikuju se od drugih kolektivnih ugovora, zbog mnogih specifičnih odredbi koje obuhvaćaju takvi kolektivni ugovori. Takve su specifične odredbe pravo na repatrijaciju, hranu i smještaj, registracija ugovora $u$ radu, zdravstvena zaštita na brodu, posebni zdravstveni uvjeti za ukrcaj na brod itd.. Može se zaključiti da je kauza takvih kolektivnih ugovora reguliranje životnih i radnih uvjeta na brodu..$^{43}$

U RH su na snazi dva kolektivna ugovora kojima se uređuje status pomoraca i to Nacionalni kolektivni ugovor za hrvatske pomorce na putničkim brodovima $i$ trajektima i Nacionalni kolektivni ugovor za hrvatske pomorce u međunarodnoj plovidbi. ${ }^{44}$

\subsection{Nacionalni kolektivni ugovor za hrvatske pomorce na putničkim brodovima i trajektima}

Nacionalni kolektivni ugovor za hrvatske pomorce na putničkim brodovima i trajektima sklopljen je 28. srpnja 1998. između Sindikata pomoraca Hrvatske i Udruge hrvatskih poslodavaca - brodara u međunarodnoj plovidbi. ${ }^{45}$ Primjenjuje se od 1. srpnja 1998. na vrijeme od dvije godine, osim dijela koji se odnosi na plaće i koji se sklapa na godinu dana. ${ }^{46}$ Ugovorne strane su se usuglasile da ako po isteku roka na koji je ugovor sklopljen niti jedna strana ne otkaže ugovor, njegovo se važenje produžuje do otkaza ili sklapanja novoga kolektivnog ugovora, odnosno aneksa. ${ }^{47} \mathrm{Po}$ isteku navedenoga roka nijedna od ugovornih strana nije otkazala predmetni kolektivni ugovor, pa se može zaključiti kako je još uvijek na snazi jer ga socijalni partneri i dalje uvažavaju i primjenjuju.

Predmetni kolektivni ugovor vrlo je detaljan te obuhvaća 125 članaka, koji su raspoređeni u 21 glavu i četiri priloga (minimalni broj članova posade, hranarina, tablica plaća i pomorski dodatak). Uređuje radne odnose pomoraca koji plove na brodovima pod hrvatskom zastavom, a kojima brodar obavlja redovni linijski pomorski prijevoz putnika i tereta u unutarnjim morskim vodama i teritorijalnom moru $\mathrm{RH}$ te u međunarodnoj plovidbi. Njime se posebno uređuje probni rad, pripravnici, raspoređivanje pomoraca, radno vrijeme, prekovremeni rad, držanje straže i naknada za rad subotom i nedjeljom, odmori i dopusti te druga specifična pitanja povezana s

42 Šarac, Crnković, Legal working status of crew members during the centuries - a comparative overview, 328.

43 Bilić, Smokvina, Problems and Perspectives of Seafarers' labour contracts in the light of Maritime Labour Convention with special refrence to Croatian legislation, 38.

44 Učur, Nacionalni kolektivni ugovor za hrvatske pomorce na brodovima na u međunarodnoj plovidbi (2013. - 2015.), 125.

45 Nacionalni kolektivni ugovor za hrvatske pomorce na putničkim brodovima i trajektima, Nezavisni sindikat pomoraca putničkih brodova Hrvatske, pristup 8. ožujka 2021., http://www. nsppbh.hr/cms.

46 Nacionalni kolektivni ugovor za hrvatske pomorce na putničkim brodovima i trajektima, čl. 115., st. 1.

47 Nacionalni kolektivni ugovor za hrvatske pomorce na putničkim brodovima i trajektima, čl. 115., st. 3. 
radom na brodu.

Nezavisni sindikat pomoraca putničkih brodova Hrvatske (dalje: NSPPBH) više je puta isticao potrebu i pozivao na pregovore predstavnike pregovaračkih odbora za pomorce oko sklapanja novoga Nacionalnog kolektivnog ugovora za hrvatske pomorce na putničkim brodovima i trajektima. NSPPBH već duže vrijeme ističe potrebu za sklapanje novoga Nacionalnog kolektivnog ugovora, posebno zbog dva važna razloga. Prvi je razlog javljanje na buduće javne natječaje za dodjelu koncesija i sklapanje ugovora o prijevozu na državnim linijama stranih konkurentnih brodarskih kompanija ${ }^{48}$ sa znatno starijim brodovima, ali s nižom cijenom rada, odnosno manjim brojem članova posade na njihovim brodovima. Zbog niže cijene rada velika je mogućnost da domaće brodske kompanije poput Jadrolinije na budućim natječajima izgube neku liniju, a gubljenje linije dovodi u pitanje radna mjesta pomoraca kao i stabilnost poslovanja brodskih kompanija. Drugi je razlog usklađivanje plaće i prava pomoraca u skladu s važećim zakonodavstvom koje bi vodilo potpisivanju Sporazuma o plaćama. NSPPBH je mišljenja da bi minimalno povećanje cijene karata definitivno dovelo do potpisivanja Sporazuma o plaćama, a Sporazum o plaćama je glavni uvjet za potpisivanje novoga Nacionalnog kolektivnog ugovora. Novim kolektivnim ugovorom regulirali bi se još formacijski sastavi brodova, odnosno broj članova posada na budućim natječajima za brodske, brzobrodske i trajektne linije te tako ojačala pozicija domaćim brodarima u odnosu na stranu konkurenciju, koja posjeduje starije brodove na kojima je manji broj članova posade u odnosu na domaće brodove.

\subsection{Nacionalni kolektivni ugovor za hrvatske pomorce na brodovima u međunarodnoj plovidbi (2021.-2022.)}

Nacionalni kolektivni ugovor za hrvatske pomorce na brodovima u međunarodnoj plovidbi (2021.-2022.) primjenjuje se od 1. siječnja 2021. Kolektivni ugovor sklopljen je na dvije godine, a ako ga nakon isteka niti jedna ugovorna strana ne otkaže, njegova se valjanost produžuje do otkaza ili sklapanja novoga Kolektivnog ugovora. Kolektivni je ugovor rezultat uspješnog pregovaranja legitimnih i reprezentativnih predstavnika - Hrvatske udruge brodara Mare Nostrum i Sindikata pomoraca Hrvatske.

Novi Kolektivni ugovor nastavak je duge i složene suradnje navedenih subjekata jer su i do sada sklapali odgovarajuće kolektivne ugovore u specifičnoj međunarodnoj plovidbi, uvažavajući posebnosti brodara, brodova, pomoraca - članova posade broda, ali i specifičnosti Sindikata pomoraca Hrvatske i njegovog članstva u ITF-u.

Autonomni je izvor prava za hrvatske pomorce te pomorce državljane RH koji imaju boravište ili prebivalište u RH, a plove na brodovima upisanim u hrvatski ili neki drugi upisnik brodova. Primjenjuje se i na pomorce državljane ostalih država članica EU-a pritom vodeći računa o primjeni odredaba Uredbe (EZ) br. 883/2004 Europskog parlamenta i Vijeća od 29. travnja 2004. o koordinaciji sustava socijalne sigurnosti. $^{49}$

48 Nikola Mandić, "Modified Legal Framework and Opening of the Liner Shipping Market in the Republic of Croatia to Shipping Companies from the European Economic Area", Transactions on Maritime Science br. 2 (2017): 144.

49 Nacionalni kolektivni ugovor za hrvatske pomorce na brodovima u međunarodnoj plovidbi 
Kolektivni ugovor obuhvaća 43 članka te ima opće i posebne dodatak. Općih dodataka ima sedam ${ }^{50}$ te obvezuje sve članice udruge potpisnice kolektivnog ugovora i sve poslodavce. Opći dodatci su: platne ljestvice, nacionalni blagdani, popis novčanih naknada, visine naknade u postotcima za tjelesno oštećenje, ugovor o zaposlenju pomoraca, lista miritelja i lista arbitara. Poseban dodatak obvezuje samo članicu potpisnicu Posebnog dodatka i poslodavca. ${ }^{51}$

Člankom 3. Kolektivnog ugovora pod nazivom zaposlenje uređuje se: sklapanje ugovora o zaposlenju; trajanje i sadržaj ugovora o zaposlenju; liječnički pregled kao poseban uvjet za sklapanje ugovora o zaposlenju; naknade troškova; obveze o dostupnosti ugovora o zaposlenju radi provjere vlastima i predstavnicima Sindikata; valjanost svjedodžbe i drugih dokumenata te obveze i odgovornosti pomoraca. Svjedoci smo da se u posljednje vrijeme postupak ukrcaja i iskrcaja pomoraca zakomplicirao jer su mnoge države zbog pojave pandemije bolesti COVID-19 uvele specifične dodatne zdravstvene preglede i mjere poput karantena, obveznoga negativnog PCR testa. Tako je novim Kolektivnom ugovoru u čl. 3. dodan st. 8. kojim se uređuje obavljanje dodatnih zdravstvenih pregleda sukladno s posebnim propisima države gdje će se izvršiti ukrcaj. ${ }^{52}$

U Kolektivnom se ugovoru ne koristi pojam ugovor o radu, već ugovor o zaposlenju. Ugovor o zaposlenju prema ovom Kolektivnom ugovoru znači ugovor o zaposlenju kojeg na temelju Kolektivnog ugovora sklapaju poslodavac s pomorcem i koji je izjednačen s pojmom ugovora o radu iz PZ-a..$^{53}$ Okvir Ugovora o zaposlenju temelji se na MLC-u, PZ-u, ZOR-u i na predmetnom kolektivnom ugovoru.

Ugovor o zaposlenju prema Kolektivnom ugovoru koji je na snazi razlikuje se od prijašnjih jer obuhvaća podatke o brodovlasniku. U slučaju proturječnosti između općih odredaba i pojedinačnog ugovora o zaposlenju primjenjuju se opće odredbe, ako su povoljnije za pomorce. Kolektivni ugovor primjenjuje se na sve ugovore o zaposlenju, uključujući i one koji su sklopljeni prije njegova stupanja na snagu. ${ }^{54}$

$\mathrm{Na}$ temelju ugovora o zaposlenju slijedi postupak ukrcaja pomorca na određeni brod. Ukrcaj i trajanje ukrcaja uređeno je čl. 6. Kolektivnog ugovora. Od trenutka ukrcaja teku prava i obveze između poslodavca i pomorca, odnosno od dana (sata) putovanja ako se brod na koji se pomorac mora ukrcati nalazi izvan teritorijalnoga mora RH.

Tijekom putovanja pomorac ima pravo na naknadu plaće i dnevnicu te

(2021.-2022.) čl. 2., st. 2. i 3.

50 Nacionalni kolektivni ugovor za hrvatske pomorce na brodovima u međunarodnoj plovidbi (2021.-2022.) za razliku od prethodna dva kolektivna ugovora ima sedam općih dodataka. Novina je opći dodatak pod nazivom platne liste koji sadrži tablice s podatcima o minimalnim plaćama pomoraca na brodovima iz posebnog dodatka (1) nosivosti preko 6.000 BT - suhi teret i tankeri.

51 U vrijeme pisanja ovoga rada još nije bio zaključen i objavljen sadržaj niti jednog posebnog dodatka.

52 Nacionalni kolektivni ugovor za hrvatske pomorce na brodovima u međunarodnoj plovidbi (2021.-2022.) čl. 2., st. 8.

53 O posadi broda opširnije vidi čl. 125.-164. Pomorskog zakonika.

54 Nacionalni kolektivni ugovor za hrvatske pomorce na brodovima u međunarodnoj plovidbi (2021.-2022.) čl. 42., st. 1. 
poslodavac mora voditi i računa da pomorac odmoran preuzme dužnost na brodu.

Pomorac se ukrcava na najviše devet mjeseci tijekom bilo kojih 12 mjeseci, ovisno o zahtjevima i području plovidbe, kao i tipu broda, sukladno s Posebnim dodatkom (3). ${ }^{55}$ Kada se ugovor o zaposlenju sklapa na određeno vrijeme, ono se utvrđuje Posebnim dodatkom (3), a ne može biti duže od šest mjeseci, samo se po izboru poslodavca može skratiti na pet mjeseci ili produžiti na sedam mjeseci. Ugovor se može sklopiti za jedno ili više putovanja koja ne mogu trajati duže od ukupno sedam mjeseci, osim za vježbenike kada se ugovor o zaposlenju može sklopiti i na rok od 12 mjeseci. ${ }^{56}$ Zbog svega prethodno navedenoga, mogućnost sklapanja ovakvog ugovora o zaposlenju jedna je od iznimaka u sklapanju ugovora o radu na određeno vrijeme prema ZOR-u..$^{57}$

Preneseno na sadržaj Kolektivnog ugovora možemo reći da je radni odnos pomoraca dobrovoljno, sporazumno, zakonom, konvencijama i preporukama te kolektivnim ugovorima i općim aktima uređeno i osnovano, neposredno obavljanje poslova na brodu od pomorca, koji se obvezao na brodu, kao član posade, kroz određeno vrijeme, kao zanimanje i uz plaću raditi u službi brodara, na temelju ugovora o zaposlenju koji na temelju Kolektivnog ugovora, zaključuje poslodavac s pomorcem..$^{58}$

U sljedećim člancima Kolektivni ugovor uređuje karakteristična pitanja radnih odnosa pomoraca: radno vrijeme, prekovremeni rad, blagdani, razdoblje odmaranja, plaća, obiteljskih doznaka, godišnjeg odmora, držanja straže, sastav i broj članova posade, nepotpuna postava posade, plovidba u ratnom području, stvari u vlasništvu pomorca; prestanak zaposlenja, repatrijacija, prehrana i smještaj, posteljina, sredstva osobne zaštite na radu, jednakost, ništavost odricanja od prava. Osim pojedinih prava koja se odnose samo na pomorsku djelatnost, riječ je o pravima koje uređuje ZOR za sve radnike u radnom odnosu, stoga autori u ovom radu analiziraju samo specifičnosti i novine tih prava kako ih uređuje ovaj Kolektivni ugovor.

Članci koji se odnose na radno vrijeme, prekovremeni rad, blagdane i razdoblje odmaranja isti su kao i u prethodnim kolektivnim ugovorima. Pritom je jedina novina u tome da se za dane blagdana i za dan sv. Nikole posadi priznaje pravo na veću hranarinu. ${ }^{59}$

Plaća je uređena čl. 11. Kolektivnog ugovora. Novina u odnosu na prethodne

55 Novim Nacionalnim kolektivnim ugovorom za hrvatske pomorce na brodovima u međunarodnoj plovidbi (2021.- 2022.) u čl. 6., st. 5. predviđena je mogućnost da u slučaju više sile i/ili okolnosti koje su izvan kontrole države zastave broda ili poslodavca poput pandemije, epidemije, rata, prirodnih katastrofa i slično produžuje se razdoblje ukrcaja pomoraca do trenutka kada je moguć siguran iskrcaj, a najduže razdoblje sukladno s posebnom dodatkom (3), uz suglasnost pomorca.

56 Nacionalni kolektivni ugovor za hrvatske pomorce na brodovima u međunarodnoj plovidbi (2021.-2022.) čl. 3., st. 3.

57 Učur, Radnopravni status pomoraca, 98-99.

58 Učur, Bartulović, Mornarska služba u srednjovjekovnim statutima i Nacionalni kolektivni ugovor za hrvatske pomorce na brodovima u međunarodnoj plovidbi, 906.

59 Redovito radno vrijeme za sve pomorce iznosi osam sati dnevno, a svakom se pomorcu jamči najmanje 103 sata prekovremenog rada prema Posebnom dodatku (2). Blagdanima se smatraju dani navedeni u Općem dodatku (2). 
kolektivne ugovore su platne ljestvice iz Općeg dodatka (1). ${ }^{60}$ Ukupna plaća svakoga člana posade broda u međunarodnoj plovidbi ne može se obračunavati u iznosu nižem od iznosa navedenih u platnim ljestvicama iz Općeg dodatka (1), a koje predstavljaju minimalne ukupne plaće pojedinih zvanja pomoraca na brodovima za suhe terete i tankere nosivosti preko $6.000 \mathrm{BT}$ i/ili sa strojem porivne snage preko $3.000 \mathrm{~kW}$. Za brodove u nižoj kategoriji plovidbe nosivosti do 6.000 BT ili sa strojem porivne snage do $3.000 \mathrm{~kW}$, plaća pomorca obračunava se na temelju ukupne plaće kormilara i ne može biti niža od minimalne osnovne plać $e^{61}$ prema Rezoluciji ILO - Joint Maritime Commission (JMC) od 19.-20. studenoga 2018. i prema zajedničkom tumačenju ITF-a i Međunarodne brodarske federacije (ISF). ${ }^{62}$ Svaki pomorac na kojeg se odnosi ovaj Kolektivni ugovor ima i pravo na isplatu obiteljske doznake u skladu s odredbama Standarda A. 2.2, stavka 5. MLC-a. ${ }^{63}$

U specifičnosti kolektivnih ugovora za pomorce spadaju stvari u vlasništvu pomorca $i$ repartijacija. Što se tiče stvari $u$ vlasništvu pomorca podrazumijeva se da od polaska na ukrcaj, pa sve do povratka s iskrcaja pomorac koristi neophodne stvari u svom vlasništvu. Ako pomorac pretrpi potpuni ili djelomični gubitak ili oštećenje na svojim osobnim stvarima iz bilo kojeg razloga, osim razloga uvjetovanoga vlastitom krivnjom, ima pravo na naknadu štete od poslodavca. Pomorac mora dokazati da je riječ o stvari za njegovu osobnu uporabu. ${ }^{64}$

Repartijacija je pravo pomorca da se nakon iskrcaja vrati u mjesto određeno ugovorom o zaposlenju (prebivalište, boravište i luka ukrcaja). Podrazumijeva troškove na teret poslodavca koji se sastoje od osnovne plaće i dnevnice sve do mjesta sklapanja ugovora o zaposlenju. Repatrijacija se pomorcu priznaje: nakon isteka vremena ukrcaja; odlukom poslodavca o raskidu ugovora o zaposlenju; $u$ slučaju potpunog gubitka broda; ako je brod u raspremi ili ako poslodavac proda brod. Pomorac ima pravo na repatrijaciju, iako je kriv za tešku povredu radne obveze ili je izvršio više lakših povreda te kad prije isteka ugovora o zaposlenju na vlastiti zahtjev traži iskrcaj. U navedenim slučajevima poslodavac mora izvršiti repatrijaciju pomoraca o svom trošku s pravom na obeštećenje od preostaloga neisplaćenog dijela plaće pomorca. ${ }^{65}$ Prema čl. 20. Kolektivnog ugovora, u postupku repatrijacije trebaju se primjenjivati odredbe MLC-a: Pravilo 2.5 Repatrijacija.

60 Opći dodatak (1) sadrži tablice s podatcima osnovne plaće, prekovremenog rada, zajamčenog prekovremenog rada, godišnjeg odmora i na kraju ukupan iznos plaće koji je zbroj osnovne plaće, zajamčenog prekovremenog rada i godišnjeg odmora ovisno o činu pomorca na brodu.

61 Prema čl. 1. Nacionalnog kolektivnog ugovora za hrvatske pomorce na brodovima u međunarodnoj plovidbi (2021.- 2022.) minimalna ukupna plaća znači ukupnost plaće s naslova redovitog radnog vremena, zajamčenog prekovremenog rada i dodatka za godišnji odmor.

62 O plaćama opširnije vidi u čl. 11. Nacionalnog kolektivnog ugovora za hrvatske pomorce na brodovima u međunarodnoj plovidbi (2021.-2022.).

63 Odnosi se na prijenos cijele ili dijela zarade svojim obiteljima, osobama koje o njima ovise ili korisnicima, čl. 11. i 12. Nacionalnog kolektivnog ugovora za hrvatske pomorce na brodovima u međunarodnoj plovidbi (2021.-2022.).

64 Nacionalni kolektivni ugovor za hrvatske pomorce na brodovima u međunarodnoj plovidbi (2021.-2022.), čl. 18.

65 Nacionalni kolektivni ugovor za hrvatske pomorce na brodovima u međunarodnoj plovidbi (2021.-2022.), čl. 20. 
Sastav posade i držanje straže uređeno je čl. 14. i 15. Kolektivnog ugovora. Stražu organizira zapovjednik broda i to u tri smjene. Stražu obavljaju svi osim zapovjednika i upravitelja stroja, osim na brodovima za opskrbu i opsluživanje naftnih i/ili plinskih platformi gdje i oni drže stražu. Kolektivni ugovor u skladu s Pravilom MLC-a 2.7. Brojno stanje posade, uređuje sastav i broj članova posade broda kako bi se u svako doba omogućila sigurna plovidba.

Odredbe čl. 17. Kolektivnog ugovora uređuju vrlo specifično pitanje i odnose koji se javljaju i uređuju samo kada su u pitanju pomorci, a odnosi se na Plovidbu u ratnim / visoko rizičnim područjima. U vezi s tim uređeno je sljedeće:

- potpisnici ovoga Kolektivnog ugovora kvartalno će izmijeniti službene informacije po objavi Zajedničkog ratnog odbora (engl. Joint War Committee - JWC) ${ }^{66}$ o činjenicama bitnim za njegovu primjenu;

- pomorac tijekom ukrcaja mora biti obaviješten da brod tijekom plovidbe prolazi kroz takva područja;

- ako brod uđe u takvo područje, pomorac ima pravo odustati od nastavka plovidbe s pravom na repatrijaciju i primanja do dana povratka;

- pravo na dvostruku osnovnu plaću za svaki dan boravka broda u takvim područjima i

- $\quad$ pravo na dvostruki iznos naknade za invaliditet i smrt koji su prouzročeni u tim područjima. ${ }^{67}$

Uređeno je i pitanje prava otetog ili zarobljenoga pomorca sve dok ne bude oslobođen do završetka ugovora ili povratka kući. ${ }^{68}$ Zbog pojave pandemije bolesti COVIDA-19 u Kolektivni ugovor dodan je čl. 17.a koji se odnosi na sigurnost i dobrobit članova posade broda u izvanrednim okolnostima, primjerice epidemije, pandemije, prirodnih katastrofa i slično.

Jedno od važnijih socijalno-pravnih pitanja odnosi se na medicinsku pomoć, liječenje i bolovanje pomorca. Poslodavac snosi troškove liječenja, uključujući i bolničko liječenje te po novom Kolektivnom ugovoru i zubarsko liječenje u hitnim slučajevima u inozemstvu.

Troškove liječenja poslodavac podmiruje sve do ozdravljenja ako nisu pokriveni redovnim zdravstvenim osiguranjem, ali najviše do 120 dana nakon repatrijacije. U odnosu na prijašnje kolektivne ugovore ovim Kolektivnim ugovorom pomorcima je priznato i pravo da nakon iskrcaja s broda, a prije repatrijacije odnosno tijekom liječenja u inozemstvu, imaju pravo na osnovnu plaću. ${ }^{69} \mathrm{U}$ slučaju bolesti, pomorac

66 Zajednički ratni odbor (JWC) čine predstavnici osiguranja s tržišta Lloyd'sa i IUA-e. Obično se sastaje tromjesečno kako bi ažurirao i distribuirao područja u kojima su vlasnici dužni obavijestiti osiguravatelje o putovanjima. Zajednički ratni odbor posljednji je put pregledavao područja u travnju 2021. te u svojoj okružnici od 29. travnja 2021. detaljno naveo područja s pretpostavljenim povećanim rizikom.

67 Nacionalni kolektivni ugovor za hrvatske pomorce na brodovima u međunarodnoj plovidbi (2021.-2022.), čl. 17.

68 Prava otetog i zarobljenog pomorca uređena su i najnovijim izmjenama MLC-a od 27. travnja 2018.

69 Nacionalni kolektivni ugovor za hrvatske pomorce na brodovima u međunarodnoj plovidbi (2021.-2022.), čll. 22. 
ima pravo na naknadu bolovanja u visini njegove osnovne plaće sve dok bolest traje, ali najduže do 120 dana nakon repatrijacije. ${ }^{70}$

Međutim, ovim su kolektivnim ugovorom dodane i odredbe koje štite poslodavca. Naime, poslodavac je ovlašten zahtijevati od pomorca da provede zdravstveni kontrolni pregled kod liječnika kojeg je osobno odredio poslodavac. Ako pomorac odbije pregled bez opravdanog razloga naknada za bolovanje će se obustaviti dok se ne utvrdi postignuti stupanj izlječenja, odnosno opravdanost daljnjega trajanja bolovanja.

Nažalost, zbog pojave sve većega broja mentalno oboljelih pomoraca, kao i povećanja broja pomoraca ovisnim o igrama na sreću i opijatima, novim Kolektivnim ugovorom dodan je i čl. 23.a kojim je propisana obveza potpisnika kolektivnog ugovora da izrade program mentalnoga zdravlja koji će se nalaziti na brodovima članicama Udruge Mare Nostrum.

Ako pomorac tijekom trajanja ugovora o zaposlenju, što uključuje i putovanje od njegova stalnog prebivališta do broda i obrnuto, doživi nezgodu od čije posljedice umre ili ako umre prirodnom smrću, poslodavac je dužan isplatiti svotu navedenu u Općem dodatku (3) imenovanom korisniku nominiranom u ugovoru o zaposlenju. ${ }^{71}$ Uz to, taksativno su navedeni razlozi kada poslodavac nije dužan isplatiti svotu navedenu u Općem dodatku (3)..$^{72}$

Kolektivnim ugovorom navedena su tri razloga prestanka zaposlenja: ${ }^{73}$

- nakon isteka ugovora o zaposlenju;

- kada je iskrcavanje obavljeno zbog bolesti ili ozljede nakon liječničkoga pregleda;

- otkazivanjem ugovora o zaposlenju od strane pomorca ili poslodavca.

Pomorac može otkazati ugovor o zaposlenju s poslodavcem ili tražiti iskrcaj:

- davanjem pisane obavijesti o otkazu ili iskrcaju poslodavcu mjesec dana unaprijed u nazočnosti dva svjedoka (što je otkaz s otkaznim rokom);

- kada bračni drug pomorca, njegovo dijete ili roditelj iznenada teško oboli tijekom putovanja;

- ako je pomorac bio zaposlen na određeno putovanje na određenom brodu, a koje je u međuvremenu znatno izmijenjeno;

- ako brod plovi u ratnom području;

- ako je brod pod zaustavljanjem 30 dana te

- zbog nepridržavanja odredbi iz Kolektivnog ugovora.

70 Čl. 23., st. 1. novoga Nacionalnog kolektivnog ugovorom za hrvatske pomorce na brodovima u međunarodnoj plovidbi (2021.-2022.) određeno je da pomorac neće imati pravo na naknadu bolovanja ako poslodavac dokaže da je bolest posljedica prethodne bolesti ili zdravstvenog stanja o čemu je pomorac propustio izvijestiti kod liječničkog pregleda radi utvrđivanja sposobnosti za ukrcanje na brod.

71 Nacionalni kolektivni ugovor za hrvatske pomorce na brodovima u međunarodnoj plovidbi (2021.-2022.), čl. 26., st. 2. uređeno je da će poslodavac o svom trošku izvršiti prijevoz posmrtnih ostataka kao i troškove ukopa.

72 Nacionalni kolektivni ugovor za hrvatske pomorce na brodovima u međunarodnoj plovidbi (2021.-2022.), čl. 26.

73 Nacionalni kolektivni ugovor za hrvatske pomorce na brodovima u međunarodnoj plovidbi (2021.-2022.), čll. 19. 
Poslodavac može raskinuti ugovor s pomorcem:

- davanjem pisanje obavijesti mjesec dana unaprijed uz nazočnost dva svjedoka;

- nakon potpunoga gubitka broda ili kad je brod stavljen u raspremu ili ako proda brod;

- zbog teške povrede radne obveze pomorca prema propisanom postupku te

- u slučaju nesposobnosti pomorca da stručno i kvalitetno obavlja poslove i radne zadatke (pomorcu se treba ponuditi mogućnost sklapanja obavljanja drugog posla i sklapanja novog ugovora).

Valja naglasiti da je posebno uređeno raskidanje ugovora o zaposlenju sa zapovjednikom broda.

Kada se uspoređuju odredbe o prestanku zaposlenja prema Nacionalnom kolektivnom ugovoru za hrvatske pomorce na brodovima u međunarodnoj plovidbi (2021.-2022.) i Nacionalnom kolektivnom ugovoru za hrvatske pomorce na putničkim brodovima i trajektima očito je da su koncipirane na različite načine. Razlog je što su kod Nacionalnog kolektivni ugovor za hrvatske pomorce na brodovima u međunarodnoj plovidbi (2021.-2022.) odredbe prilagođene zaposlenju određenog trajanja, a kod Nacionalnog kolektivnog ugovora za hrvatske pomorce na putničkim brodovima i trajektima ZOR-u i prestanku ugovora o radu. ${ }^{74}$

Za pomorce je jako važan čl. 27. Kolektivnog ugovora koji propisuje da će poslodavac zaključiti odgovarajuće osiguranje, odnosno održavati na snazi sustav financijskog osiguranja u slučaju njihova napuštanja u skladu s MLC-om za svoje potpuno pokriće naknade štete u slučajevima proizašlima iz Kolektivnog ugovora.

Brod nije samo mjesto rada, već je i mjesto življenja pomorca, pa je poslodavac obvezan osigurati pomorcu prehranu, smještaj, udobnost, kuhinju, jednokratan pristup besplatnom pozivu, rekreaciju, a sve u skladu sa standardom MLC-a specificiranim u Pravilu 3.1 - Prostorije za smještaj i Pravilu 3.2 - Prehrana i posluživanje hrane. ${ }^{75}$ Iz toga proizlazi da je jedna od glavnih obveza poslodavca omogućiti pomorcima komuniciranje s obitelji brodskim sustavom veza, uključujući upotrebu elektroničke pošte i interneta tijekom njihova boravka na brodu, vodeći računa o sigurnosti plovidbe.

Osiguranje sredstava osobne zaštite na radu za pomorca tijekom njegova boravka na brodu obveza je poslodavca sukladno s odredbama čl. 29. Kolektivnog ugovora. Sve osobe uključene u rad moraju imati na raspolaganju i nositi propisana osobna zaštitna sredstva, a poseban režim ima odjeća za spašavanje u dostatnom broju i zahtijevanim standardima. ${ }^{76}$

Stranke potpisnice obvezale su se da će najmanje jednom godišnje razmatrati i

74 Bilić, Smokvina, Problems and Perspectives of Seafarers' labour contracts in the light of Maritime Labour Convention with special refrence to Croatian legislation, 40.

75 Nacionalni kolektivni ugovor za hrvatske pomorce na brodovima u međunarodnoj plovidbi (2021.-2022.), čl. 28.

76 Nacionalni kolektivni ugovor za hrvatske pomorce na brodovima u međunarodnoj plovidbi (2021.-2022.), čl. 29.; pobliže regulirano Zakonom o zaštiti na radu, Narodne novine, br. 71/14., 118/14., 154/14., 94/18. i 96/18.; Međunarodnim pravilnikom o upravljanju sigurnošću (ISM Code) - SMS pravilima i standardima; Pravilom 4.3. Zaštita zdravlja i sigurnosti iz MLC-a. 
ispitivati uvjete Kolektivnog ugovora, a za rujan 2021. već je dogovoreno kolektivno pregovaranje o izmjenama i dopunama odredbi ovog Kolektivnog ugovora kojima su uređena materijalna prava pomoraca. ${ }^{77}$

Za kraj treba dodati da je Kolektivni ugovor sastavljen na hrvatskom i engleskom jeziku, a u slučaju neusklađenosti teksta, za njegovo tumačenje i primjenu mjerodavan je hrvatski jezik. ${ }^{78}$

\section{ZAKLJUČAK}

Pomorci u odnosu na druge djelatnosti na kopnu imaju specifičan radni status koji je posebno uređen. Zbog toga je upravo najveći broj konvencija i preporuka MOR-a donesen u svezi s radom pomoraca. Unatoč tome, pomorci se i dalje suočavaju s brojnim poteškoćama vezanim za njihov radnopravni položaj zbog nepostojanja općeprihvaćenog i provedivog regulatornog režima. Najveći uspjeh po pitanju uređenja radnopravnih odnosa pomoraca učinjen je usvajanjem MLC-a.

Uz MLC kao važnog izvora prava za reguliranje radnog statusa pomoraca u RH javljaju se i Kolektivni ugovori. Oni čine neposredni pravni temelj za ostvarivanje i zaštitu prava, obveza i odgovornosti pomoraca kod određenog brodara. Za kolektivne ugovore koji se odnose na pomorce karakteristične su brojne specifične odredbe kojih nema u drugim takvim ugovorima, a koje se tiču javnopravnoga karaktera radnih odnosa pomoraca. U RH su na snazi dva kolektivna ugovora kojima se uređuje status pomoraca: Nacionalni kolektivni ugovor za hrvatske pomorce na putničkim brodovima i trajektima i Nacionalni kolektivni ugovor za hrvatske pomorce na brodovima $u$ međunarodnoj plovidbi (2021.-2022.).

Nacionalni kolektivni ugovor za hrvatske pomorce na brodovima u međunarodnoj plovidbi (2021.-2022.) nastavak je uspješnoga kontinuiranog socijalnog dijaloga Hrvatske udruge brodara Mare Nostrum i Sindikata pomoraca Hrvatske, koji rezultira novim nacionalnim kolektivnim ugovorima za hrvatske pomorce u međunarodnoj plovidbi skoro svake dvije godine. S druge strane, potpuno je suprotna praksa glede regulacije radnopravnog i socijalnog statusa putem kolektivnih ugovora za hrvatske pomorce na putničkim brodovima i trajektima gdje je posljednji kolektivni ugovor sklopljen daleke 1998.

U kontekstu njihovih radnih odnosa najveći dio pritužbi pomoraca odnosi se na plaće (neisplata plaće, neprosljeđivanje zarađene plaće njihovim obiteljima) i ugovor o zaposlenju. Upravo zbog toga je Nacionalni kolektivni ugovor za hrvatske pomorce na brodovima u međunarodnoj plovidbi (2021.-2022.) detaljno razradio pojam ugovora o zaposlenju pomoraca kao i načine prestanka zaposlenja. Također, vezano za plaće u odnosu na prethodne kolektivne ugovore donesen je opći dodatak (1) koji uređuje minimalne plaće pomoraca na brodovima za suhi teret i tankerima preko $6.000 \mathrm{BT}$.

77 Nacionalni kolektivni ugovor za hrvatske pomorce na brodovima u međunarodnoj plovidbi (2021.-2022.), čl. 38.

78 Nacionalni kolektivni ugovor za hrvatske pomorce na brodovima u međunarodnoj plovidbi (2021.-2022.), čl. 42., st. 2. 
Zbog pojave sve veće konkurencije u pogledu jeftine radne snage novim nacionalnim kolektivnim ugovorom u međunarodnoj plovidbi prepoznata je i potreba kontinuiranog ukrcaja vježbenika kao jednog od glavnih uvjeta za razvoj hrvatskoga pomorstva.

Iz navedenog je vidljivo da je sadržaj novoga kolektivnog ugovora $u$ međunarodnoj plovidbi nadograđen u smjeru što veće zaštite radnih i socijalnih prava pomoraca, kao i u smjeru obrazovanja i obuke novih pomoraca koji će nastaviti dugu i uspješnu tradiciju kvalitetnih i dobro obučenih hrvatskih pomoraca koji plove u međunarodnoj plovidbi. Poboljšanje zaštite pomoraca najbolje se očituje kroz mogućnost da ovlašteni predstavnici Sindikata pomoraca Hrvatske / ITF-a mogu posjetiti i pregledati bilo koji brod na kojem su zaposleni članovi Sindikata pomoraca Hrvatske. Poslodavac je dužan dati na uvid sve odgovarajuće isprave kojima se dokazuje primjena kolektivnoga ugovora.

Također, na inicijativu Sindikata pomoraca Hrvatske krajem siječnja 2021. Ministarstvo mora, prometa i infrastrukture je prema naputku IMO-a i UN-a, proglasilo pomorce ključnim radnicima u RH. Tim činom nadležno Ministarstvo dalo je veliki doprinos u olakšavanju akutnih i trenutnih poteškoća s kojima se pomorci diljem svijeta suočavaju, a ponajprije u odnosu na nemogućnost organizacije smjena posade i repatrijacije pomoraca.

Bitno je istaknuti potrebu sklapanja novoga Nacionalnog kolektivnog ugovora za hrvatske pomorce na putničkim brodovima i trajektima, čije bi odredbe omogućile što bolje prilagođavanje domaćih brodara novim uvjetima na tržištu linijskoga prijevoza. Naime, od 2018. svi brodari iz Europskoga gospodarskog prostora mogu se prijaviti na natječaje za dodjelu koncesija i sklapanje ugovora na državnim linijama za linijski prijevoz unutarnjim morskim vodama i teritorijalnom moru RH, a Kolektivni ugovor iz 1998., koji je trenutno na snazi, domaće brodare dovodi u nepovoljniji položaj u odnosu na europsku konkurenciju.

Zaključno, napori koji su do sada učinjeni rezultirali su podizanjem životnih i radnih uvjeta (standarda) pomoraca. Međutim, još postoji prostor za unaprjeđenje onih radnih i socijalnih prava pomoraca kod kojih je zabilježen najveći broj nepravilnosti pri inspekciji brodova, a to su: ugovor o zaposlenju, obračun i isplata plaće, propisani broj i struktura posade. Unaprjeđenje radnopravnih uvjeta, kao i zaštite pomoraca jamstvo je poštenih i humanih uvjeta na brodu, a što je važno za sigurnost plovidbe i zaštitu morskog okoliša.

\section{LITERATURA}

1. Bartulović, Željko i Maja Aflić. „Sailor's Service from Medieval Times to Modern Maritime Labour Conventions“. Zbornik Pravnog fakulteta Sveučilišta u Rijeci 55, br. 1 (2018): 167-182.

2. Bilić, Andrijana i Vanja Smokvina. „Problems and Perspectives of Seafarers' labour contracts in the light of Maritime Labour Convention with special refrence to Croatian legislation”. U: Zbornik radova - 3. Međunarodna znanstvena konferencija pomorskog prava Suvremeni izazovi pomorske plovidbe (Split, 8.-9. travnja 2021.), ur. Petra Amižić, Mirko Klarić, Dragan Bolanča, Vesna Skorupan, Božena Bulum, Mitja Grbec, 11-47. 
Split: Pravni fakultet 2021.

3. Blanck, John Issac. „Reflections on the Negotiation of the Maritime Labour Convention 2006 at the International Labour Organisation”. Tulane Maritime Law Journal 31 (2007): 35-54.

4. Buklijaš, Boris i Adrijana Bilić. Međunarodno radno pravo. Split: Pravni fakultet, 2006.

5. Božiković, Nenad. „Tržišste rada u Europskoj uniji i Republici Hrvatskoj“. Zbornik Pravnog fakulteta Sveučilišta u Rijeci 42, br. 1. (2021): 91-110.

6. Grabovac, Ivo i Ranka Petrinović. Pomorsko pravo, pomorsko javno, upravno i radno pravo. Split: Pomorski fakultet, 2006.

7. Jelić Mrčelić, Gorana, Nikola Mandić i Ranka Petrinović. „Environmental Impact of Ships - International Legislative Framework ”. U: International Legislative Framework, ur. Stephen de Mora, Timothy Fileman, Thomas Vance, 329-351. Cambridge: Cambridge Univeristy Press, 2020.

8. Konvencija o radu pomoraca, 2006., Pomorski glasnik. Zagreb: Ministarstvo mora, turizma, prometa i razvitka, 2006.

9. Mandić, Nikola. „Modified Legal Framework and Opening of the Liner Shipping Market in the Republic of Croatia to Shipping Companies from the European Economic Area". Transactions on Maritime Science br. 2 (2017): 140-146.

10. Maul, Daniel. The International Labour Organization, 100 years of global social policy. Berlin: De Gruyter Oldenbour, 2019.

11. McConnell, Moira L. „The Maritime Labour Convention, 2006 - reflections on challenges for flag State implementation". WMU Journal of Maritime Affairs br. 10 (2011): 127-141.

12. Međunarodni pravilnik o upravljanju sigurnošću (ISM Code), Uredba (EZ) br. 336/2006 od 15. veljače 2006.

13. Nacionalni kolektivni ugovor za hrvatske pomorce na putničkim brodovima i trajektima. Pristup 8. ožujka 2021. http://www.nsppbh.hr/cms

14. Nacionalni kolektivni ugovor za hrvatske pomorce u međunarodnoj plovidbi, Narodne novine, br. $6 / 21$.

15. Odluka Vijeća EU 2997/431/EC od 7. lipnja 2010.

16. Petrinović, Ranka, Trpimir Perkušić i Tony Vuković, Tony. „Inspection of Seafarers' working Conditions in Accordance with MLC 2006 in Ports of Paris MOU Signatories", $\mathrm{U}$ : Zbornik radova - 3. Međunarodna znanstvena konferencija pomorskog prava Suvremeni izazovi pomorske plovidbe (Split, 8.-9. travnja 2021.), ur. Petra Amižić, Mirko Klarić, Dragan Bolanča, Vesna Skorupan, Božena Bulum, Mitja Grbec, 177-207. Split: Pravni fakultet, 2021.

17. Pomorski zakonik, Narodne novine, br. 181/04., 76/07., 146/08., 61/11., 56/13., 26/15. i $17 / 19$.

18. Rozić, Ivo. Kolektivno radno pravo. Sarajevo: JP NIO Službeni list BIH, 2013.

19. Međunarodna organizacija rada. Pristup 17. prosinca 2020. www.ilo.org

20. Sindikat pomoraca Hrvatske. Pristup 18. prosinca 2020., www.sph.hr

21. Šarac, Marina i Andrija Crnković. „Legal working status of crew members during the centuries- a comparative overview”. U: Zbornik radova - 3. Međunarodna znanstvena konferencija pomorskog prava Suvremeni izazovi pomorske plovidbe (Split, 8.-9. travnja 2021.), ur. Petra Amižić, Mirko Klarić, Dragan Bolanča, Vesna Skorupan, Božena Bulum, Mitja Grbec, 311-333. Split: Pravni fakultet 2021.

22. Učur, Marinko Đ. i Željko Bartulović. „Mornarska služba u srednjovjekovnim statutima i Nacionalni kolektivni ugovor za hrvatske pomorce na brodovima u međunarodnoj plovidbi (2013-2015)“. U: Zbornik radova- Međunarodna znanstvena konferencija Uslužni poslovi, ur. Miodrag Mićović, 897-923. Kragujevac: Pravni fakultet 2014.

23. Učur, Marinko Đ. „Kolektivno pregovaranje i proširenje primjene kolektivnog ugovora (oktroiranje kolektivnog ugovora)“. Zbornik radova Pravnog fakulteta Sveučilišta u Rijeci 27, br. 1 (2006): 543-570. 
24. Učur, Marinko Đ. „Nacionalni kolektivni ugovor za hrvatske pomorce na brodovima u međunarodnoj plovidbi (2013. - 2015.)". Naše more 61, br. 5-6 (2014): 118-125.

25. Učur, Marinko Đ., Radnopravni status pomoraca. Rijeka: Pravni fakultet, 2003.

26. Zakon o radu, Narodne novine, br. 93/14., 127/17. i 98/19.

27. Zakon o zaštiti na radu, Narodne novine, br. 71/14., 118/14., 154/14., 94/18. i 96/18. 


\author{
Ivo Rozić* \\ Tony Vuković** \\ Nenad Božiković $* * *$
}

\section{Summary \\ COLLECTIVE AGREEMENTS AS A SOURCE OF RIGHTS FOR REGULATING THE SEAFARERS' LABOUR STATUS IN THE REPUBLIC OF CROATIA}

The seafarers' employment agreement is one of the most specific ones. Seafarers are a special category of workers, because their place of work is also their place of living. Working conditions differ in many ways from the working and living conditions of workers in other economic activities performed on land. Therefore, the legal regulation of the seafarers' employment status is particularly important. The greatest success in these terms was made with the adoption of the Maritime Labor Convention $(M L C), 2006$, which was ratified by the Republic of Croatia in February 2010. In the Republic of Croatia there is no legal act in full regulating working, social and living conditions since such provisions are contained in several regulations. Collective agreements are particularly important acts. Two such collective agreements are in force in the Republic of Croatia - the National Collective Agreement for Croatian Seafarers on Passenger Ships and Ferries concluded in 1998 and the National Collective Agreement for Croatian Seafarers on Ships in the International Shipping Trade (2021-2022), which has been in force since 2021. In this paper, the authors give an overview of the Seafarers' Labour Convention, characteristics of the concept and process of collective bargaining. They in particular analyze the applicable collective agreement with focus on the National Collective Agreement for Croatian Seafarers in the International Shipping Trade (2021-2022).

Keywords: seafarers' labour status; Maritime Labor Convention (MLC); collective bargaining; the National Collective Agreement for Croatian Seafarers on Passenger Ships and Ferries; the National Collective Agreement for Croatian Seafarers on Ships in the International Shipping Trade.

\footnotetext{
* Ivo Rozić, Ph.D., Full Professor, University of Mostar, Faculty of Law; ivo.rozic@pf.sum.ba. ORCID: https://orcid.org/0000-0003-0074-1450.

** Tony Vuković, mag. iur., Doctoral Student, University of Mostar, Faculty of Law; tonyvukovich@pfst.hr. ORCID: https://orcid.org/0000-0003-3370-1324.

*** Nenad Božiković, Ph.D., External Associate, Banja Luka College; jbozikovina@gmail.com. ORCID: https://orcid.org/0000-0001-6140-0639.
} 
